\title{
EVALUATION OF SERUM CREATININE LEVEL IN SUBCLINICAL HYPOTHYROIDISM
}

\section{Deepa Thadani}

\section{Manna Lal} Kumawat*

\section{Sarla Mahawar}

\section{Ajay Jain}

\author{
Sr. Professor \& Head, Department Of Biochemistry, JLN Medical College,
} Ajmer, Rajasthan, India- 305001.

Post Graduate Resident, Department Of Biochemistry, JLN Medical College, Ajmer, Rajasthan, India- 305001. *Corresponding Author

Professor, Department Of Biochemistry, JLN Medical College, Ajmer, Rajasthan, India- 305001.

Assistant Professor, Department Of Biochemistry, JLN Medical College, Ajmer, Rajasthan, India- 305001.

\section{ABSTRACT}

Background: Hypothyroidism is a common endocrinal disorder caused by insufficient production of thyroid hormones. Subclinical hypothyroidism (SCH) can be defined as a state of high serum thyroid stimulating hormone (TSH) levels (less than $10 \mu \mathrm{IU} / \mathrm{ml}$ ) with normal serum free thyroxine $\left(\mathrm{fT}_{4}\right)$ and triiodothyronine $\left(\mathrm{fT}_{3}\right)$ levels in the presence or absence of symptoms. Creatinine is a chemical waste product that is produced by muscle metabolism. Creatinine is produced from creatine, a molecule of major importance for energy production in muscles. Thyroid dysfunction can affect renal physiology and development, and on the other hand, kidney disorders can influence thyroid function. This study was aimed to find out the status of serum $\mathrm{fT}_{3}, \mathrm{fT}_{4}, \mathrm{TSH}$ and serum creatinine levels in subclinical hypothyroid cases and healthy controls. Materials and Methods: The present study is descriptive case control study, was conducted in the Department of Biochemistry, J.L.N. Medical College and Associated group of Hospitals, Ajmer (Raj.). 130 cases of subclinical hypothyroidism attending Medical OPD of J.L.N. Hospitals were included and 50 age-sex matched euthyroid controls were selected. Results: The mean serum creatinine levels were found to be significantly high in subclinical hypothyroid cases(0.99 $\pm 0.19 \mathrm{mg} \%)$ as compared to healthy controls $(0.75+0.15 \mathrm{mg} \%),(\mathrm{p}<0.0001)$. Conclusion: Serum creatinine can be used as a biomarker for early detection of subclinical hypothyroidism in general population to prevent the morbidity and mortality which are associated with hypothyroidism. Early diagnosis and intervention of subclinical hypothyroid and their cluster of risk factor can prevent the renal dysfunction.

\section{KEYWORDS : Triiodothyronine $\left(\mathrm{T}_{3}\right)$, Thyroxine $\left(\mathrm{T}_{4}\right)$, Thyroid stimulating hormone(TSH), Chemiluminescence} Immunoassay(CLIA) , Subclinical hypothyroidism(SCH), Overt hypothyroidism (OHT), Glomerular filtration rate (GFR)

\section{INTRODUCTION}

The hormones produced by thyroid gland are thyroxine $\left(\mathrm{T}_{4}\right)$ and triiodothyronine $\left(\mathrm{T}_{3}\right)$, which act through $\alpha$ and $\beta$ receptors. These hormones play a crucial role in general development and metabolism, normal growth, tissue differentiation, physiology of the kidney, maintain thermogenic and metabolic homeostasis in the adults. ${ }^{(1)}$ Deficiency of thyroid hormones cause hypothyroidism, which is one of the most common endocrine disorder nowadays. The disease causes generalized slowing of metabolic processes. ${ }^{(5,6)}$ Hypothyroidism presents with low production of thyroid hormones, affecting 2$15 \%$ of population worldwide. Incidence is higher in women compared to men. ${ }^{(6,7)}$ Subclinical hypothyroidism is a common disorder, particularly in middle aged and elderly individuals. ${ }^{(13)}$

Subclinical hypothyroidism ( $\mathrm{SCH}$ ) can be defined as a state of high serum thyroid stimulating hormone (TSH) levels (less than $10 \mu \mathrm{IU} / \mathrm{ml}$ ) with normal serum free thyroxine $\left(\mathrm{fT}_{4}\right)$ and triiodothyronine $\left(\mathrm{fT}_{3}\right)$ levels in the presence or absence of symptoms. ${ }^{(2,3,4)}$ The prevalence of $\mathrm{SCH}$ is between $3 \%$ and $18 \%$ in the general population and higher in women than in men. ${ }^{(15)}$ It is the mildest form of hypothyroidism and the patients usually lack classical signs and symptoms of overt hypothyroidism. ${ }^{(13)} \mathrm{SCH}$ patients are at risk for progression to overt hypothyroidism with an average yearly progression rate of $2 \%$ to $6 \%$ with an increased risk in females. ${ }^{(15)}$ Subclinical hypothyroidism carries the risk of developing overt hypothyroidism with subsequent cardiovascular health risks and renal dysfunction. ${ }^{(16)}$

Creatinine is a chemical waste product that is produced by muscle metabolism. Creatinine is produced from creatine, a molecule of major importance for energy production in muscles. Thyroid dysfunction can affect renal physiology and development, and on the other hand, kidney disorders can influence thyroid function. Serum creatinine is elevated and glomerular filtration rate (GFR) values are reversibly reduced in overt hypothyroid patients than in euthyroid subjects. ${ }^{177}$ Hypothyroidism affects every tissue in the body resulting in declination of mental and physical activities. The increased serum creatinine concentration is due to reduction of glomerular filtration rate because of hemodynamic changes in case of hypothyroidism. Serum creatinine may also be increased due to hypothyroid myopathy. ${ }^{(21)}$

Subclinical primary hypothyroidism is suspected to be mostly due to chronic autoimmune thyroiditis, characterized by a mild asymptomatic goiter and high titer of serum thyroid autoantibodies. ${ }^{(23,24)}$ Other less common causes include druginduced hypothyroidism, subacute thyroiditis, radiation thyroiditis, and postpartum thyroiditis. . $^{(23,25)}$

\section{MATERIALS AND METHODS}

The present study is descriptive case control study, was conducted in the Department of Biochemistry, J.L.N. Medical College and Associated group of Hospitals, Ajmer (Raj.). 130 cases of subclinical hypothyroidism attending Medical OPD of J.L.N. Hospitals were included and 50 age-sex matched euthyroid controls were selected. Venous blood sample were collected from all the participants under aseptic precaution and serum was separated and biochemical parameters of this study were measured by following methods-Thyroid Profile ( $\mathrm{fT}_{3}, \mathrm{fT}_{4}, \mathrm{TSH}$ ) by- Chemiluminescence Immunoassay method and serum creatinine by-Jaffe's colorimetric kinetic method. The present study was approved by institutional ethical committee.

\section{For control group}

Age and sex matched healthy individuals. 
Inclusion Criteria for study group

Age group between $20-50$ year of both sex diagnosed as $\mathrm{SCH}$ individuals.

Exclusion Criteria for study group

- Persons with hypothyroidism.

- Persons with coronary artery disease

- Persons with diabetes or those with stroke

- Persons with a history of arthritis

- Smokers/alcohol users

- On diuretics

- Thyroid supplementation and antithyroid agents.

- Persons using drugs that affect serum creatinine

- Pregnant women

Statistical analysis

All data were analysed by SPSS-13 version. $\mathrm{P}<0.01$ were considered as significant.

\section{RESULTS}

A total of 180 subjects were studied. The results are summarized in Tables and Figures. The Table-1, Figure-1 shows that the Mean \pm SD of weight and BMI were more in subjects with subclinical hypothyroidism than healthy subjects and the difference was significant $(P<0.001)$. The Mean \pm SD of height was less in subjects with subclinical hypothyroidism than healthy subjects (controls) and the difference was significant $(\mathrm{P}<0.001)$ while the mean age was not significant $(\mathrm{P}>0.005)$.

Table- 1 Anthropometric Parameters of Healthy subjects v/s Subjects with subclinical hypothyroidism

\begin{tabular}{|c|c|c|c|}
\hline Parameters & $\begin{array}{c}\text { GROUP-I } \\
\text { Healthy } \\
\text { subjects } \\
\text { Mean } \pm \mathrm{SD} \\
(\mathrm{n}=50)\end{array}$ & $\begin{array}{c}\text { GROUP-II } \\
\text { Subjects with } \\
\text { subclinical } \\
\text { hypothyroidism } \\
\text { Mean } \pm \mathrm{SD}(\mathrm{n}=130)\end{array}$ & $\begin{array}{c}\text { P- } \\
\text { Value }\end{array}$ \\
\hline Age(yrs.) & $40.08 \pm 8.83$ & $40.27 \pm 7.89$ & $>0.005$ \\
\hline Height $(\mathrm{cm})$ & $162.86 \pm 7.54$ & $157.89 \pm 7.22$ & $<0.001$ \\
\hline Weight $(\mathrm{kg})$ & $63.03 \pm 5.16$ & $69.39 \pm 5.34$ & $<0.001$ \\
\hline BMI $\left(\mathrm{kg} / \mathrm{m}^{2}\right)$ & $23.75 \pm 0.82$ & $27.85 \pm 1.52$ & $<0.001$ \\
\hline
\end{tabular}

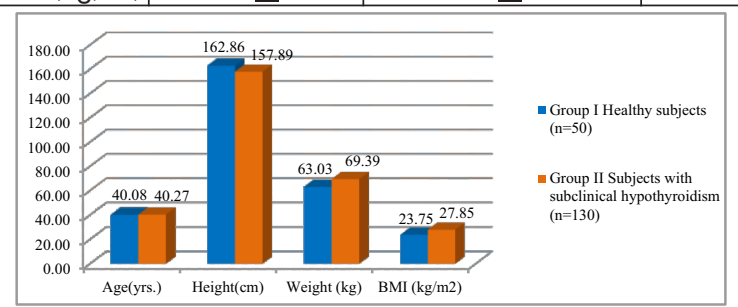

Fig- 1 Comparison of Anthropometric Parameters of Healthy subjects v/s Subjects with Subclinical hypothyroidism.

Table-2, Figure-2 shows distribution of subclinical hypothyroidism among female and male subjects. Among the total number of 130 subjects with subclinical hypothyroidism in our study were $102(78 \%)$ females and male patients were $28(22 \%)$ in the ratio of 3.6:1.

Table :2 -Distribution of subclinical hypothyroidism among female and male subjects

\begin{tabular}{|c|c|c|}
\hline $\begin{array}{c}\text { Female with subclinical } \\
\text { hypothyroidism }\end{array}$ & $\begin{array}{c}\text { Male with subclinical } \\
\text { hypothyroidism }\end{array}$ & Total \\
\hline $102(78 \%)$ & $28(22 \%)$ & 130 \\
\hline
\end{tabular}

Subjects with subclinical hypothyroidism ( $\mathrm{n}=\mathbf{1 3 0}$ )

Fig -2 Distribution of subclinical hypothyroidism among female and male subjects
Table -3 , Figure -3 shows age wise distribution among subclinical hypothyroid subjects. There is increase in distribution of number of subjects with subclinical hypothyroidism as the age advances from 20 years to 50 years. The distribution of number of subclinical hypothyroid cases with age wise distribution is age between 20-25 $n=11,26-30 n=15,31-35$ $n=17,36-40 n=24,41-45 n=28$ and $46-50 n=35$.

Table-3 Age wise distribution among total number of subclinical hypothyroidism subjects

\begin{tabular}{|c|c|}
\hline $\begin{array}{c}\text { Age Groups } \\
\text { (in years) }\end{array}$ & $\begin{array}{c}\text { Subjects with Subclinical Hypothyroidism } \\
(\mathrm{n}=130)\end{array}$ \\
\hline $20-25$ & 11 \\
\hline $26-30$ & 15 \\
\hline $31-35$ & 17 \\
\hline $36-40$ & 24 \\
\hline $41-45$ & 28 \\
\hline $46-50$ & 35 \\
\hline Total & 130 \\
\hline
\end{tabular}

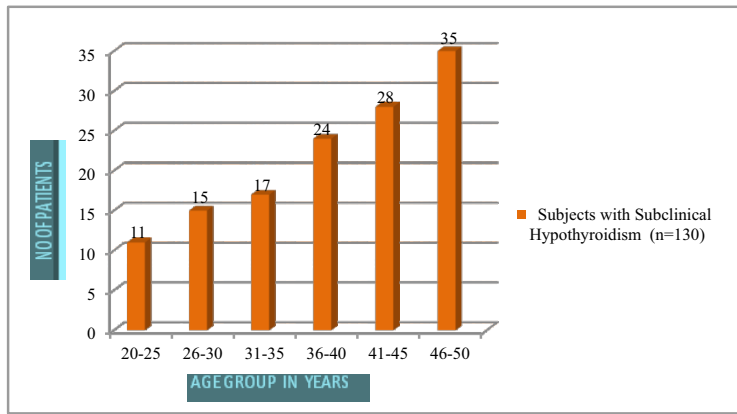

Fig- 3 Age wise distribution among total number of subclinical hypothyroidism subjects

Table-4, Figure- 4 shows the Mean $\pm \mathrm{SD}$ of serum $\mathrm{fT}_{3}(3.06 \pm$ $0.20 \mathrm{v} / \mathrm{s} 3.25 \pm 0.22) \mathrm{pg} / \mathrm{ml} \mathrm{fT}_{4}(0.75 \pm 0.07 \mathrm{v} / \mathrm{s} 0.81 \pm 0.0 .07)$ $\mathrm{ng} / \mathrm{dl}$ in subjects with subclinical hypothyroidism compared to healthy subjects (controls) was significantly $(\mathrm{P}<0.0001)$ decreased. The Table-2, Figure-2 also shows that the level of serum TSH $(7.52 \pm 1.18 \mathrm{v} / \mathrm{s} 2.52 \pm 1.13) \mu \mathrm{IU} / \mathrm{ml}$, serum creatinine $(0.99 \pm 0.19 \mathrm{v} / \mathrm{s} 0.75 \pm 0.15) \mathrm{mg} \%$ in subjects with subclinical hypothyroidism compared to healthy subjects (controls) were significantly $(\mathrm{P}<0.0001)$ raised

Table-4 Comparison of Biochemical Parameters of Healthy subjects v/s Subjects with subclinical hypothyroidism

\begin{tabular}{|c|c|c|c|}
\hline Biochemical Parameters & $\begin{array}{c}\text { Group-I } \\
\text { Healthy } \\
\text { Subjects } \\
\text { Mean+ SD } \\
(\mathrm{n}=50)\end{array}$ & $\begin{array}{c}\text { Group-II } \\
\text { Subjects with } \\
\text { subclinical } \\
\text { hypothyroidism } \\
\text { Mean } \pm \text { SD } \\
(\mathrm{n}=130)\end{array}$ & $\begin{array}{c}\mathrm{P} \\
\text { value }\end{array}$ \\
\hline $\begin{array}{l}\mathrm{fT}_{3} \text { (tri - iodothyronine) } \\
(\mathrm{pg} / \mathrm{ml})\end{array}$ & $3.25 \pm 0.22$ & $3.06 \pm 0.20$ & $<0.0001$ \\
\hline $\mathrm{fT}_{4}$ (thyroxine) (ng/dl) & $0.81 \pm 0.07$ & $0.75 \pm 0.07$ & $<0.0001$ \\
\hline $\begin{array}{l}\text { TSH (thyroid stimulating } \\
\text { hormone) }(\mu \mathrm{IU} / \mathrm{ml})\end{array}$ & $2.52 \pm 1.13$ & $7.52 \pm 1.18$ & $<0.0001$ \\
\hline serum creatinine (mg\%) & $0.75 \pm 0.15$ & $0.99 \pm 0.19$ & $<0.0001$ \\
\hline
\end{tabular}

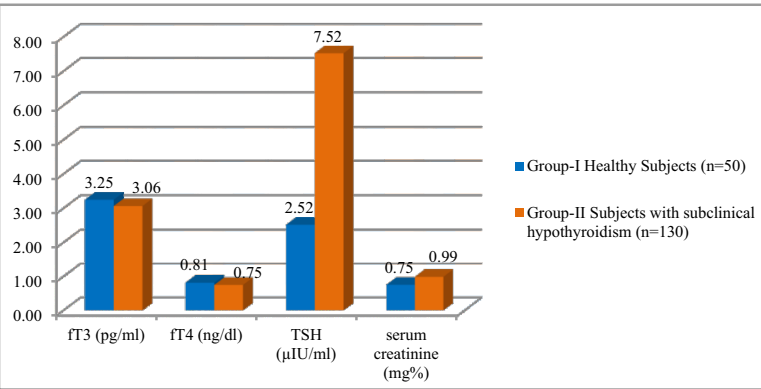

Fig-4 Comparison of Biochemical Parameters of Healthy subjects v/s Subjects with Subclinical hypothyroidism 


\section{DISCUSSION}

In recent years, subclinical hypothyroidism is unknowingly emerging as a major public health problem in India and it produces an enormous burden on the economy of the country due to high prevalence, risk of progression to overt hypothyroidism and it can lead to adverse cardiovascular consequences. Subclinical hypothyroidism (SCH) and Overt hypothyroidism $(\mathrm{OH})$ are common in the elderly people especially in the women. Subclinical hypothyroidism carries the risk of developing overt hypothyroidism, subsequent cardiovascular health risks and renal dysfunction. Hypothyroidism causes generalized slowing of metabolic processes. ${ }^{(5,6)}$ Subclinical hypothyroidism is a common disorder, particularly in middle aged and elderly individuals. ${ }^{(13)}$

Presence of thyroid antibody raises the risk of developing subclinical and then progressing to overt hypothyroidism. Role of iodine is somewhat controversial and iodine sufficient area have higher incidence of developing $\mathrm{SCH}$ than the iodine insufficient. ${ }^{(22)}$ A community based longitudinal study of 11 years has also reported an association of weight change and $\mathrm{SCH} .{ }^{(26)}$

In the present study weight and BMI were more in subjects with subclinical hypothyroidism than healthy subjects (controls) and difference was statistically significant $(p<0.001)$ while the mean age and sex matched were not significant ( $p>0.005)$, it also shows that the mean height was less than controls and the difference was significant.

Our findings are in concordance with Kumar P. et al. (2018) which also showed that body mass index ( BMI) was higher in $\mathrm{SCH}$ group (26.44 $\pm 2.19 \mathrm{~kg} / \mathrm{m} 2$ ) compared to control group $\left(21.98 \pm 1.40 \mathrm{~kg} / \mathrm{m}^{2}\right){ }^{(41)}$

Present study shows that the prevalence of sub clinical hypothyroidism is more in females when compare to males. Our findings are in concordance with study done by Manisha Panchal et al.(2019) which showed that female and male subjects with subclinical hypothyroidism were $68 \%$ and $32 \%$ respectively ${ }^{(40)}$ A similar previous study done by Bashir $\mathrm{H}$ et al.(2013) also shows that prevalence of subclinical hypothyroidism was more in female subjects as compare to males. $^{(29)}$

It is evident that there is increase in number of cases of subclinical hypothyroidism as the age advances from 20 years to 50 years. Our studies are in agreement with $\mathrm{S}$. Senthilkumaran et al. (2015) which also show increase in number of cases of subclinical hypothyroidism as the age advances. ${ }^{(30)}$

Our study shows that serum $\mathrm{fT}_{3}$, serum $\mathrm{fT}_{4}$ level were less and serum TSH was more in subjects with subclinical hypothyroidism than healthy controls and difference was statistically highly significant $(\mathrm{P}<0.0001)$. A similar trend was reported in a study done by Bhutal MB et al. (2020) which also suggest that serum $\mathrm{ft}_{3}$, serum $\mathrm{fT}_{4}$ levels were significantly lower and serum TSH was significantly higher in subjects with subclinical hypothyroidism as compared to normal healthy controls. ${ }^{(18)}$

Previous studies show that in hypothyroidism there is decreased myocardial contractility and stroke volume with increased peripheral vascular resistance, which reduces the effective renal plasma flow and GFR, causing decreased clearance of creatinine which leads to elevation of serum creatinine levels. ${ }^{(19,20)}$ The increased serum creatinine concentration is due to reduction of glomerular filtration rate because of hemodynamic changes in case of hypothyroidism. Serum creatinine may also be increased due to hypothyroid myopathy. ${ }^{(21)}$

The present case-control study evaluated the biochemical marker of renal function such as creatinine in subjects with subclinical hypothyroidism and compared the results with those of healthy euthyroid controls. The present study concludes that there is significant increase in serum creatinine levels in subclinical hypothyroid subjects as compared to healthy controls. Similar changes in serum creatinine with hypothyroidism have been evaluated in support of the present study. ${ }^{(18,19,31-39)}$

\section{CONCLUSION}

Serum creatinine was found to be elevated in subjects with subclinical hypothyroidism. There is a probable scope of reversing the decline in renal function in subjects with subclinical hypothyroidism. Serum creatinine can be used as a biomarker for early detection of subclinical hypothyroidism in general population to prevent the morbidity and mortality which are associated with hypothyroidism. Early diagnosis and intervention of subclinical hypothyroidism and their cluster of risk factor can prevent the renal dysfunction and progression of subclinical hypothyroidism to overt hypothyroidism(OHT). Based on the laboratory investigations and symptoms, subjects of $\mathrm{SCH}$ need to be monitored and treated individually.

\section{REFERENCES}

1. Lalit Singh, Abhishek Jain, Anurag Agrawal, Rajeev Tandon, Hemant Kumar. A study of prevalence of thyroid disorders in chronic obstructive pulmonary disease patients at a tertiary care center in U.P. International Journal of Contemporary Medical Research. 2016;3:1239-1242.

2. Ghanshyam Palamaner Subash Shantha, Anita Ashok Kumar et al Prevalence of subclinical hypothyroidism in patients with end-stage renal disease and the role of serum albumin: a cross-sectional study from South India :Cardiorenal Med 2011;1:255-260

3. Helfand M, Rdfern CC: Clinical guideline, part 2. Screening for thyroid disease: and update. American college of physicians. Ann Intern Med, 1998; 129: $144-58$

4. Surks MI, Ortiz E, Daniels GH, et al. Subclinical thyroid disease. Scientific review and guidelines for diagnosis and management. JAMA 2004; 291:228-238.

5. Jamesson JL, Weetman AP. Disorders of thyroid gland. In: Fauci AS, Braunwald E, Kasper DL, Hauser SL, Longo DL, Jameson JL et al, editors.Harrison's principle of internal medicine.18thedition.USA: Mc Graw Hill, 2012;2:2911-2922.

6. Fakhar UN Nisa, Asim Mumtaz, Muhammad Ikram Ulla, Muhammed Atif and Waqas Sami. Determination of serum zinc and magnesium levels in patients with hypothyroidism. Trace Elements and Electrolytes. 2014;1-5.

7. Hollowell JG, Staehling NW, Flanders WD, et al. Serum TSH, T, and thyroid antibodies in the United States population (1988 to 1994): National Health and Nutrition Examination Survey (NHANES III).J Clin Endocrinol Metab. 2002;87:489-99.

8. Abbas MM, Mahamoud AH, El-Desouky W. Biochemical changes in serum lipids fractions, calcium, magnesium and phosphorous levels in women with subclinical hypothyroidism. Nat Sci 2013;11(5):113-118.

9. Pearce SH, Brabant G, Duntas LH, Monzani F, Peeters RP, Razvi S, et al. ETA Guideline: Management of subclinical hypothyroidism. Eur Thyroid J. 2013;2(4):215-28

10. Shekhar R, Chowdary NVS, Das MC, Vidya D, Prabodh S. Prevalence of subclinical hypothyroidism in coastal Andhra Pradesh. Biomedical Research. 2011;22(4):471-44

11. Cooper DS, Biondi B. Subclinical thyroid disease. Lancet 2012;379:1 142-54.

12. Simon H.S. Pearce et al, 2013 ETA Guideline: Management of Subclinical Hypothyroidism. Eur Thyroid J 2013;2:215-228.

13. Canaries GJ, Manowitz NR, Mayor G, Ridgway EC. The Colorado thyroid disease prevalence study. Arch Intern Med. 2000;160(4):526-34.

14. Khan MA, Ahsan T, Rehman UL, Jabeen R, Farouq S. Subclinical Hypothyroidism: Frequency, clinical presentations and treatment indications. PakJ Med Sci. 2017;33(4):818-822.

15. Christine Baumgartner, Manuel R. Blum, Nicolas Rodondi. Subclinical hypothyroidism: summary of evidence in 2014. Swiss Med Wkly 2014;144:w14058.

16. Abhilash Chandra .The Dilemma of Subclinical Hypothyroidism in Chronic Kidney Disease. Journal of The Association of Physicians of India .2018(66) :76-79

17. Iglesias P, Bajo MA, Selgas R, Díez JJ. Thyroid dysfunction and kidney disease: An update. Rev Endocr Metab Disord 2017;18:131-44.

18. Bhutal MB, Mannangi NB, Kavitha MM, et al. A comparative study of serum creatinine and uric acid levels in subclinical and overt hypothyroidism patients. J. Evid. Based Med. Healthc. 2020; 7(15), 800-804.

19. Iglesias P, Diez JJ. Thyroid dysfunction and kidney disease. Eur J Endocrinol 2009;160(4):503-515.

20. Tayal D, Chawla R, Arora S et al. Dynamic changes in biochemical markers of renal function with thyroid status - a study in Indian population. Internet Journal of Medical Update 2009;4(2):36-41.

21. Khan AH, Majumder I. Serum creatinine and uric acid levels of hypothyroid 
patients. Bangladesh J Med Biochem 2010;3(2):61-63.

22. Szabolcs I Podoba I, Feldkamp I, Dohan O, Farkas I Sajgó M, et al. Comparative screening for thyroid disorders in old age in area of iodine deficiency, long-term iodine prophylaxis and abundant iodine intake. Clin Endocrinol (Oxf) 1997; 47:87-92.

23. Giovanni Targher, Michel Chonchol et al: Prevalence of thyroid autoimmunity and subclinical hypothyroidism in persons with chronic kidney disease not requiring chronic dialysis. Clin Chem Lab Med 2009;47(11):1367-1371

24. Papi G et al. Subclinical hypothyroidism. Curr Opin Endocrinol Diabetes Obes 14: 197-208, 2007

25. Malyszko J, Malyszko J : Adinonectin, leptin and thyroid hormones in patients with chronic renal failure and on renal replacement therapy: Are they related? Nephrol Dial Transplant 2006;21:145-52.

26. Bjergved L, Jørgensen T, Perrild H, Laurberg P, Krejbjerg A, et al. (2014) Thyroid Function and Body Weight: A Community Based Longitudinal Study. PLoS ONE 9: 93515.

27. Chaudhury H S, Raihan K K, Uddin M N, Ansari S M, Hasan M, Ahmed M, et al. Renal function impairment in hypothyroidism. Bangladesh J Med Biochem. 2013:6:19-25.

28. Gonella Geetha Meenakshi Renal dysfunction in hypothyroid patients estimation of blood urea, serum creatinine, $\mathrm{T}_{3}, \mathrm{~T}_{4}$ and TSH International Journal of Contemporary Medical Research 2016;3(10):2915-2917.

29. Bashir H, Farooq R, Bhat MH, Majid S: Increased prevalence of subclinical hypothyroidism in females in mountainous valley of Kashmir. Indian J Endocrinol Metab., 2013; 17(2): 276-280.

30. S. Senthilkumaran, V. Sathyaprakash, A. Sundhararajan . A Study on Prevalence and Distribution of Subclinical Hypothyroidism in Rural Women .Sch. J. App. Med. Sci., 2015; 3(1D):287-290.

31. Patil VP Shilpasree AS, Patil VS, Pravinchandra KR. Ingleshwar DG, Vani AC. Evaluation of renal function in subclinical hypothyroidism. J Lab Physicians 2018;10:50-5.

32. Mamatha B.V. , Rakshitha M.N, Kashinath R.T. , Laya Rose Thomas. Evaluation of serum urea and creatinine levels in subclinical hypothyroidism - A case control study. Medica Innovatica.2016;vol-5, 1-6

33. Vaneet Kaur, Kamaljit Singh, Minni Verma. Changes in biochemical markers of renal function in subclinical and overt hypothyroidism. Int. J. Bioassays, $2015 ; 4$ (04), 3799-3802

34. Nagarajappa K, Sushma BJ, Shweta RH. Study of thyroid stimulating hormone, serum creatinine and uric acid levels in patients with hypothyroidism. Int J Pure App Biosci 2014;2(2):187-190.

35. Ajaykumar N, Shanthi M, Parameswari R. The Effect of L-thyroxine on metabolic parameters in newly diagnosed primary hypothyroidism. International Journal of Pharmaceutical Science Invention 2013;2(8):14-18.

36. Saini V, Yadav A, Arora MK, Arora S, Singh R, Bhattacharjee J. Correlation of creatinine with TSH levels in overt hypothyroidism - a requirement for monitoring of renal function in hypothyroid patients? Clin Biochem. 2012;45:212-4

37. Sinisa S, Daniela G, Todor G, et al. Impact of thyroid dysfunction on serum cystatin C, serum creatinine and glomerular filtration rate. Maced J Med Sci 2011;4(1):25-30.

38. Arora S, Chawla R, Tayal D, et al. Biochemical markers of liver and kidney function are influenced by thyroid function- a case controlled follow up study in Indian hypothyroid subjects. Indian J Clin Biochem 2009;24(4):370-374.

39. Kreisman SH, Hennessey JV. Consistent reversible elevations of serum creatinine levels in severe hypothyroidism. Arch Intern Med 1999;159(1):7982.

40. Manisha Panchal, Umesh B Gondaliya. A study of high sensitive $\mathrm{C}$ reactive protein in subclinical hypothyroidism. International Journal of Contemporary Medicine Surgery and Radiology. 2019;4(1):A85-A87.

41. Kumar P, Sharma P, Sharma R, Gupta G, Choudhary. A Low-grade Inflammation in Subclinical Hypothyroidism: Role of High-Sensitive creactive Protein. Asian J Pharm Clin Res, Vol 11, Issue 9, 2018; 356-359. 